\title{
DECAPOD CRUSTACEANS INHABITING LIVE AND DEAD COLONIES OF THREE SPECIES OF ACROPORA IN THE ROQUES ARCHIPELAGO, VENEZUELA*
}

\author{
by \\ ALEJANDRO GRAJAL P. \& ROGER LAUGHLIN G. \\ Fundación Científica Los Roques, Apartado No. 1, Carmelitas, Caracas 1010 A, Venezuela
}

\section{SUMMARY}

A systematic account is given of the decapod crustaceans found in live and dead colonies of three species of the scleractinian coral Acropora (A. cervicornis, A. palmata, A. prolifera), collected during a 9 month period in a shallow reef flat in the southwestern portion of the Archipelago Los Roques, Venezuela.

A total of 1900 individuals belonging to 30 species were found. Some qualitative observations on the ecology, feeding, and reproduction of some decapod species are given.

Most of the species collected were found in the dead portions of the colonies. The crab Domecia acanthophora seems to be the only true commensal that depends on the live coral tissue.

The carideans Latreutes fucorum and Alpheus simus, the anomuran Pagurus brevidactylus, the brachyurans Portunus vocans and Tetraxanthus bidentatus are reported for the first time in Venezuela.

\section{RESUMEN}

En este trabajo se presentan aspectos sistemáticos y biológicos de las especies de crustáceos decápodos encontradas en partes vivas y muertas de colonias de tres especies del coral Acropora (A. cervicornis, A. palmata y A. pro'ifera). Estas colonias se colectaron durante un período de 9 meses en un arrecife coralino somero ubicado al extremo sur-oeste del Archipiélago de Los Roques, Venezuela.

Se capturaron un total de 1900 individuos pertenecientes a 30 especies. Se dan observaciones sobre la ecología, alimentación y reproducción de algunas de ellas.

Una gran parte de las especies registradas se encontró en la parte muerta de las colonias. Solamente el cangrejo Domecia acanthophora parece ser un verdadero comensal que depende del tejido vivo del coral.

Los carideos Latreutes fucorum y Alpheus simus el anomurido Pagurus brevidactylus y los branquiuros Portunus vocans y Tetraxanthus bidentatus son los primeros registros para Venezuela.

* Scientific contribution No. 12 of the Fundación Científica Los Roques.

\section{INTRODUCTION}

In recent years the study of decapod crustaceans associated to coral species has received much attention from marine biogeographers and ecologists. However, because most of the research has been conducted in the Indo-Pacific (Patton, 1966; Knudsen, 1967; Garth, 1974; Abele, 1976; Castro, 1976; Glynn, 1980; Abele \& Patton, 1967; Prahl et al., 1978; Bak \& Robertson, 1980; Edwards \& Emberton, 1980; Austin et al., 1980) and in the subtropical Atlantic (McCloskey, 1970; Reed et al., 1982), there is little information on the occurrence, distribution and geographic range of Caribbean coral-inhabiting decapods. Patton's (1967) work in Puerto Rico was conducted exclusively on a single coral associated species, Domecia acanthophora, whereas Garth's (1978) and Velez's (1977) research involved extensive reef collections without intensive sampling on specific coral species.

The present paper, a first of a series on the ecology of decapod crustaceans inhabiting acroporid corals in the Archipelago Los Roques, Venezuela, provides a systematic account and other relevant information on the decapod species found in three species of the coral Acropora.

\section{GEOGRAPHIC SETTING AND STUDY AREA}

The Archipelago Los Roques is an insular reef complex located at about $150 \mathrm{~km}$ north of the north central coast of Venezuela (fig. 1). 


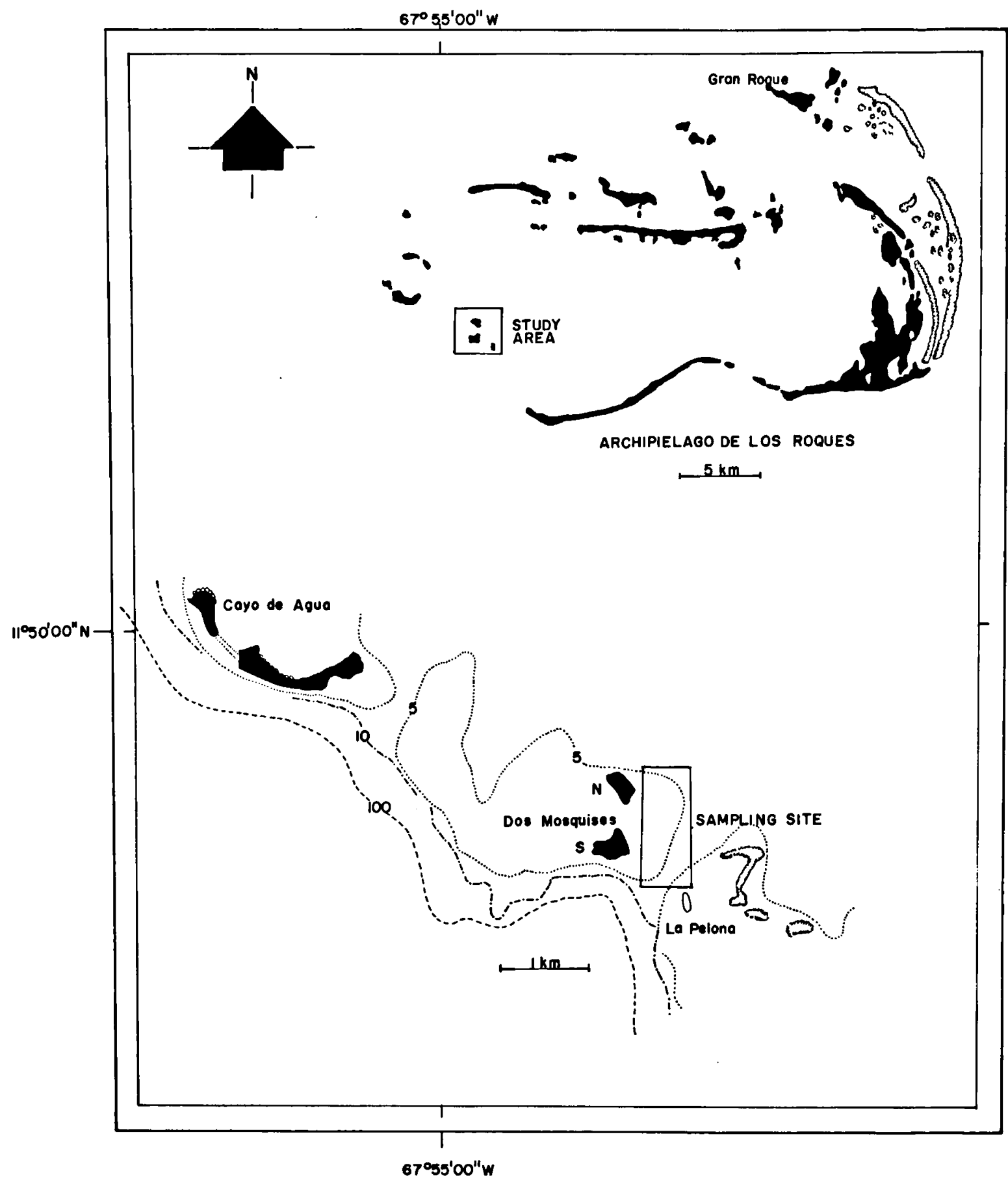

Fig. 1. The Archipiélago de los Roques (top) with location of general study area and sampling site (bottom).

Roughly, it forms an irregular oval of $36.6 \mathrm{~km}$ $\times 24.6 \mathrm{~km}$ on the east-west and north-south axis, respectively. It is formed by 42 islands and more than 200 sandbanks and reefs distributed around a shallow lagoon (depth 1-5 m) in its centro-meridional portion.

The Archipelago, or more precisely the semiatoll, rests on a submarine igneous plateau 
that rises sharply from depths of 900 to $1800 \mathrm{~m}$. The winds and oceanic currents are predominantly from the east-northeast. The climate in the islands could be classified as aridhumid with an average annual precipitation of $300 \mathrm{~mm}$.

The study was conducted on a reef flat at the leeward side of a horseshoe-shaped barrier reef that connects Dos Mosquises Norte and Dos Mosquises Sur, two nearby keys located at the extreme southwestern corner of the archipelago (fig. 1). The reef flat, with a depth of 0.7 to 1.2 $\mathrm{m}$, has an extensive coral cover of Acropora, viz. A. palmata (Lamarck, 1816), A. prolifera (Lamarck, 1816), and $A$. cervicornis (Lamarck, 1816), although the corals Porites spp., Agaricia spp., and Montastrea annularis (Ellis \& Solander, 1786), the octocorals Plexaura spp. and Gorgonia spp., and the hydrozoan Millepora complanata Lamarck, 1816, are also common. Water temperatures measured at the dock of the Marine Station at Dos Mosquises, less than 1 $\mathrm{km}$ away from the study site, varied from $25^{\circ} \mathrm{C}$ in winter (November-February) to $31^{\circ} \mathrm{C}$ in summer. Salinity ranged from 38.4 to $39.3 \%$.

\section{MATERIAL AND METHODS}

Sampling was conducted from January to November, 1981 , and involved the in situ removal of 30 colonies of each Acropora species. The cumulative curve of number of decapod species versus number of removed colonies for each coral species indicated that 30 colonies was more than enough to collect most decapod species; the asymptote in the curve was reached at 14 colonies in $A$. palmata, 26 in $A$. prolifera, and 19 in $A$. cervicornis. The selected colonies were of a size which permitted handling and transportation. Each colony was covered by a highly resistent polyethylene bag to prevent the escape of the fauna, broken off at its base with a hammer and a chisel, and immediately transported to the Marine Laboratory where the colony was completely broken up to remove the crustacean fauna.

The live portion of the coral was weighed separately from the dead portion, thus permitting the estimation of live coral weight for each colony. Field observations on location, feeding and reproduction of conspicuous crustaceans were recorded on a submersible note board.

Specimens were preserved in a $7 \%$ formalin-seawater solution with few drops of glycerin, identified, catalogued, transferred to an alcohol solution and stored in the Museum of the Fundación Científica Los Roques at Caracas, Venezuela.
Morphometric measurements were made with a calibrated vernier and an ocular micrometer mounted in a Wild M8 stereomicroscope.

In Anomura and Brachyura, carapace width (C.W.) and length (C.L.) were measured and presented in that order, while in Natantia only carapace length was measured.

The symbol $q$ ov. refers to ovigerous females, and $\$$ to non-ovigerous ones. The abbreviation "juv." refers to juveniles.

\section{RESULTS}

Before presenting the systematic account of the decapod crustaceans found in coral colonies of Acropora spp., it is important to mention that the plastic bag-enclosing method did not provide accurate information of the location on the colony of the specimens collected.

However, the vast majority of them were observed on the dead portions of the colonies. In fact, a statistical correlation made between the percent (\%) weight of live coral and the number of individuals of the four most numerous species found (Domecia acanthophora, Mythrax sculptus, Microphris bicornutus, and Thor manningi), showed significant negative relationships for 3 of the species (table I). A positive correlation was found only for $D$. acanthophora.

A list of 1900 individuals from 30 species is reported in the following systematic account:

Suborder NATANTIA

Section CaRidea

Family PALAEMonidaE

Genus Periclimenes Costa, 1844

Periclimenes americanus (Kingsley, 1878)

Refs.: Holthuis, 1951: 60, pl. 19 figs. a-e; Williams, 1965: 43, fig. 36; Rodríguez, 1980: 90 fig. 27.

Material: $40^{\circ}, 1 \&, 2 \propto$ ov., 1 juv. in $A$. prolifera; $30^{\circ}, 5$ \& ov., 9 juv. in $A$. cervicomis.

Size: $2.1 \mathrm{~mm}$ juv. to $5.9 \mathrm{~mm}$ ơ C.L.

Range: Bahamas, North Carolina to Florida, West Indies.

Remarks: This tiny shrimp can be found com- 
TABLE I

Pearson correlation coefficients between percent (\%) weight of the live coral colony and number of individuals for the four most numerous species found in colonies of Acropora spp., collected from January through November, 1981.

\begin{tabular}{|c|c|c|c|}
\hline \multicolumn{4}{|c|}{ CORAL SPECIES } \\
\hline & A. cervicornis & A. prolifera & A. palmata \\
\hline \multicolumn{4}{|l|}{ DECAPOD SPECIES } \\
\hline Mythrax sculptus & $\begin{array}{c}r=-0.33 \\
(n=443)(1)\end{array}$ & $\begin{array}{c}r=-0.42 \\
(n=96) \quad(2)\end{array}$ & $(*)$ \\
\hline Microphris bicomutus & $\begin{array}{c}r=-0.37 \\
(n=80) \quad(1)\end{array}$ & $(*)$ & $(*)$ \\
\hline Thor manningi & $(*)$ & $\begin{array}{c}r=-0.48 \\
(n=153)(2)\end{array}$ & $(*)$ \\
\hline Domecia acanthophora & $\begin{array}{c}r=0.79 \\
(n=159)(3)\end{array}$ & $\begin{array}{c}r=0.56 \\
(n=487)(3)\end{array}$ & $(*)$ \\
\hline
\end{tabular}

(1) $=p<0.09 \quad(2)=p<0.01 \quad(3)=p<0.005$

$\left({ }^{*}\right)=$ The number of individuals was too low for statistical analysis.

monly in shallow waters in coral, algae, and rocks. Seen on dead portions of the coral.

\section{Periclimenes iridescens Lebour, 1949}

Ref.: Holthuis, 1951: 43, pl. 12, pl. 20 figs. $i-j$.

Material: $20^{\circ} ; 3$ ov. in A. cervicomis.

Size: $1.7 \mathrm{~mm}$ o' to $2.6 \mathrm{~mm}$ \% ov. C.L. Range: Bermuda, Cubagua island, Venezuela; in sand and algae to $100 \mathrm{~m}$.

\section{Periclimenes rathbunae Schmitt, 1924}

Ref.: Holthuis, 1951: 58, pl. 17.

Material: 1 juv. in A. cervicornis.

Size: $2.9 \mathrm{~mm}$ C.L.

Range: Lesser Antilles.

Remarks: This species has been reported as a commensal of sea anemones, specially of Stoichactis helianthus (Ellis, 1767), commonly found on the dead portions of Acropora.

Genus Periclimaneus Borradaile, 1915

\section{Periclimaneus bermudensis (Armstrong, 1940)}

Refs.: Holthuis, 1951: 107, pl. 32 figs. d-g, pl. 33; Rodríguez, 1980: 93, fig. 28.

Material: $10^{\circ}$ in $A$. prolifera.

Size: $1.6 \mathrm{~mm}$ C.L.

Range: Dry Tortugas, Bermuda, Bahamas, Los Roques; found inside Callyspongia and other sponges in shallow water.

Genus Brachycarpus Bate, 1888

\section{Brachycarpus biunguiculatus (Lucas, 1846)}

Refs.: Holthuis, 1951: 3, pl. 1; Rodríguez, 1980: 96, fig. 30.

Material: 2 ov. in $A$. prolifera.

Size: 7.1 and $7.3 \mathrm{~mm} \mathrm{C.L.}$

Range: Pantropical.

Remarks: It has been reported as a nocturnal cleaner (Criales \& Corredor, 1977). Both specimens were found in a small cavity in a dead basal portion of $A$. prolifera.

Family ALPHEIDAE

Genus Alpheus Fabricius, 1798 
Alpheus cristulifrons Rathbun, 1900

Refs.: Crosnier \& Forest, 1966: 260, figs. 17-18; Rodríguez, 1980: 143, fig. 40 l-m.

Material: $120^{\circ}, 23$ ov., 1 juv. in $A$. prolifera; $40^{\circ}, 5$ \% ov., 2 juv. in $A$. cervicornis; $2 \sigma^{\circ}, 2 \bigcirc$ ov. in $A$. palmata.

Size: From $2.2 \mathrm{~mm}$ juv. to $12.3 \mathrm{~mm}$ ९ ov. C.L.

Range: Tropical Atlantic, Los Roques; in shallow water in coral, Halimeda, and sponges. Remarks: Most specimens were found in heterosexual pairs inhabiting small cavities of the dead portion of Acropora. In all pairs, the male was smaller (C.L.) than the female.

Alpheus ridleyi Pocock, 1890

Refs.: Crosnier \& Forest, 1966: 230; Rodríguez, 1980: 149, fig. 42 d-f.

Material: $10^{\circ}, 19$ ov. in A. cervicornis.

Size: $10.8 \mathrm{~mm}$ or and $22.3 \mathrm{~mm}$ \% ov. C.L. Range: Bahamas to Fernando Norhona, Brazil; in shallow water in rocks and pieces of coral.

Remarks: Both specimens were found inhabiting the same cavity at the basal dead portion of the colony.

\section{Alpheus simus Guérin-Méneville, 1856}

Ref.: Guérin-Méneville, 1856: xix, pl. 2 fig. 11.

Material: $1 \sigma^{\circ}, 1 \%$ in $A$. prolifera.

Size $6.0 \mathrm{~mm}$ o and $3.7 \mathrm{~mm}$ \% C.L. Range: Cuba, Curaçao, Los Roques.

Remarks: This enigmatic species, senior synonym of Crangon rathbunae, is a new report for Venezuela. Both specimens were found inside a small crevice at the dead basal portion of the colony, and both were of a clean white color when collected.

Genus Synalpheus Bate, 1888

Synalpheus apioceros Coutière, 1909

Refs.: Williams, 1965: 69, fig. 56; Rodríguez, 1980: 155. Material: $2 \sigma^{\circ}, 1$ juv. in $A$. prolifera.

Size: 1.6 juv. to $6.5 \mathrm{~mm}$ ơ C.L.
Range: Florida to Surinam, in shallow water, mangroves and sand.

Remarks: Found inside small crevices in dead basal portions of the colony.

Synalpheus curacaoensis Schmitt, 1924

Ref.: Schmitt, 1924: 66, fig. 3.

Material: $10^{\circ}, 1 \%$ ov., 1 juv. in $A$. prolifera.

Size: $1.7 \mathrm{~mm}$ juv. to $4.5 \mathrm{~mm} \&$ ov. C.L.

Range: Curaçao, Bonaire; in shallow water, under rocks and pieces of coral, and in the zoanthid Zoanthus sociatus (Ellis, 1767).

Remarks: Found inside small crevices in dead basal portions of the colonies.

\section{Synalpheus fritzmuelleri Coutière, 1909}

Refs.: Williams, 1965: 69, fig. 56; Rodríguez, 1980: 153.

Material: $50^{\circ}, 1 \%, 4 \%$ ov. in $A$. prolifera; $70^{\circ}, 1 \%, 3$ \% ov. in A. cervicornis; $10^{\circ}, 1 \%$ in $A$. palmata.

Size: $1.8 \mathrm{~mm}$ o to $5.7 \mathrm{~mm}$ ơ C.L.

Range: North Carolina and Bermuda, to Santa Catarina, Brazil; Baja California; to $50 \mathrm{~m}$ in mangroves and coral rubble.

Remarks: Found inside small crevices in dead portions of the colonies.

Synalpheus pandionis Coutière, 1909

Refs.: Coutière, 1909: 67, fig. 39; Rodríguez, 1980: 161

Material: $1 \sigma^{\circ}$ in $A$. prolifera.

Size: $4.6 \mathrm{~mm}$ C.L.

Range: Gulf of Mexico to Barbados; to $60 \mathrm{~m}$, in sand, coral rubble and rocks.

Remarks: Found inside small crevices in the dead basal portion of the colony.

Family HIPPOLITIDAE

Genus Thor Kingsley, 1878

Thor cf. manningi Chace, 1972

Ref.: Chace, 1972: 13, figs. 59-61.

Material: $67 \sigma^{\circ}, 33$ \&, 28 \% ov., 25 juv., with 2 \% parasitized by an unidentified isopod in $A$. prolifera; $20^{\circ}$, $8 \%, 16 \%$ ov., 8 juv. in $A$. cervicornis; $2 \sigma^{*}, 1$ \& 1 \& ov. in A. palmata. 
Size: $1.1 \mathrm{~mm}$ juv. to $3.2 \mathrm{~mm}$ or in C.L. Range: North Carolina to Curaçao, and westward to Yucatán; to a depth of $44 \mathrm{~m}$.

Remarks: This polymorphic species is difficult to identify and only a few of the males had a prehensile dactylus in the third pereiopod, as Chace (1972) remarks. This tiny shrimp was seen swimming from branch to branch of the corals, even on live portions of the colonies.

Genus Latreutes Stimpson, 1860

Latreutes fucorum (Fabricius, 1798)

Ref.: Williams, 1965: 78, fig. 63.

Material: 29 ov. in $A$. cervicornis.

Size: $3.6 \mathrm{~mm}$ and $3.2 \mathrm{~mm}$ C.L.

Range: Western North Atlantic between $10^{\circ}$ and $50^{\circ} \mathrm{N}$, Azores and Cape Verde Islands; pelagic and sublittoral.

Remarks: This is a new report for Venezuela. Usually found in floating Sargassum and other seaweeds.

\section{Section STENOPODIDEA}

Family STENOPODIDAE

Genus Stenopus Latreille, 1819

Stenopus scutellatus Rankin, 1898

Ref.: Rankin, 1898: 242, pl. 29 fig. 3.

Material: $1 \sigma^{\circ}$ in $A$. prolifera.

Size: $15.0 \mathrm{~mm}$ C.L.

Range: Bahamas and Gulf of Mexico, to Fernando Noronha, Brazil.

Remarks: This species has been reported as a nocturnal cleaner (Criales \& Corredor, 1977) often found in heterosexual pairs. Observed on the dead basal portion of the colony with an ovigerous female that escaped from the plastic bag.

Suborder ANOMURA

Section GaLATHEIDEA

Family PORGElanidae

Genus Petrolisthes Stimpson, 1858
Petrolisthes galathinus (Bosc, 1802)

Ref.: Gore \& Abele, 1976: 702.

Material: $90^{\circ}, 2$ \%, 3 ov., 5 juv. in $A$. prolifera.

Size: From $2.6 \mathrm{~mm} \times 2.9 \mathrm{~mm}$ juv. to $8.6 \times$ $8.3 \mathrm{~mm} Q$ ov.

Range: Cape Hatteras to South Brazil, including the Caribbean. Also known from the Pacific.

Remarks: Observed only on dead portions of the colonies.

\section{Section PAguridea}

Family PAGURIDAE

Genus Paguristes Dana, 1851

Paguristes cadenati Forest, 1954

Refs.: Forest, 1954: 353-357, figs. 3-4; Provenzano, 1961: 325.

Material: $10^{\circ}, 1 \%, 4$ ov. in $A$. prolifera.

Size: From $4.2 \times 6.8 \mathrm{~mm}$ \& to $12.5 \times 8.5 \mathrm{~mm}$ O".

Range: Florida, Guadeloupe, Curaçao; between 5 and $15 \mathrm{~m}$.

Remarks: Found on dead portions of the colonies.

Genus Pagurus Fabricius, 1775

Pagurus brevidactylus (Stimpson, 1862)

Ref.: Provenzano, 1959: 413, fig. 20.

Material: $1 \sigma^{\circ}, 29$ ov. in $A$. cervicomis; $10^{\circ}$ in $A$. prolifera.

Size: From $1.8 \times 3.5 \mathrm{~mm}$ or to $4.5 \times 2.8 \mathrm{~mm}$ on.

Range: North Carolina, southwestern Florida, West Indies to Barbados.

Remarks: A new report for Venezuela, found on the dead portions of the colonies.

Pagurus marshi Benedict, 1901

Ref.: Provenzano, 1959: 405, fig. 17.

Material: $60^{\circ}, 1 \%, 5 \%$ ov. in $A$. cervicomis; 20, 1\%, 1 juv. in $\boldsymbol{A}$. prolifera. 
Size: From $1.2 \times 2.8 \mathrm{~mm}$ juv. to $7.6 \times 8.0$ mm ơ.

Range: Florida, Puerto Rico, Curaçao.

Remarks: Found on the dead portions of the colonies.

Pagurus miamensis Provenzano, 1959

Refs.: Provenzano, 1959: 414, fig. 21; Rodríguez, 1980: 232.

Material: $30^{\circ}, 1 \%, 29$ ov. in $A$. prolifera; $20^{\circ}$ in $A$. cervicornis

Size: $2.0 \times 2.7 \mathrm{~mm}$ \& ov. to $4.7 \times 6.0 \mathrm{~mm}$ \&. Range: Bahamas, Florida, Curaçao and Venezuela; in sublittoral to $3 \mathrm{~m}$.

Remarks: Found on the dead portions of the colony. A female in $A$. cervicornis was found with a parasitic isopod on the ventral side of the abdomen.

Suborder BRACHYURA

Section BRAGHYGNATHA

Superfamily BRACHYRHINCHA

Family Xanthidae MacLeavy, 1838

Genus Domecia Eydoux \& Souleyet, 1842

Domecia acanthophora forma acanthophora Desbonne \& Schramm, 1867

Ref.: Guinot, 1964: 271, figs. 4, 5, 6, 7, 8, 15.

Material: $19 \sigma^{\circ}, 18 \%, 21 \%$ ov., and 14 juv. in A. palmata; $97 \circ^{\circ}, 56 \%, 51 \%$ ov., and 283 juv. in $A$. prolifera; $670^{\circ}$, 44 \&, 21 \% ov., 27 juv. in A. cervicornis.

Size: $1.7 \times 1.4 \mathrm{~mm}$ juv, to $11.5 \times 8.7 \mathrm{~mm}$ ơ . Range: Tropical Atlantic among sponges and branches of the corals Acropora and Porites furcata (Rathbun, 1925).

Remarks: This is by far the most common decapod crustacean collected. It is believed to produce structural modifications in A. palmata, which Patton (1967) named "resting places". These crevices and pits can be found in the upper portions of the corals and between branches. No structural deformations were observed in the upper portions of the other two Acropora species. Most crabs found in $A$. palmata crevices were ovigerous females, thus the sex ratio was
$1: 2.05$ for $A$. palmata, as compared to $1: 1.1$ and $1: 0.97$ for $A$. prolifera and $A$. cervicornis, respectively. This species seems to be the only true commensal of acroporid corals in the Caribbean.

Genus Chlorodiella Rathbun, 1897

Chlorodiella longimana (H. Milne Edwards, 1834)

Ref.: Rathbun, 1930: 462, pl. 186.

Material: $80^{\circ}, 4 \%, 2$ ov., 6 juv. in $A$. prolifera; $10^{\circ}, 1$ juv. in $A$. cervicornis.

Size: From $2.5 \times 2.0 \mathrm{~mm}$ juv. to $21.3 \times 13.2$ $\mathrm{mm} \mathrm{O}^{\circ}$.

Range: Florida and Curaçao.

Remarks: Casually found on live portions of the coral.

Genus Micropanope Stimpson, 1871

Micropanope spinipes A. Milne Edwards, 1880

Ref.: Rathbun, 1930: 443, pl. 181 figs. 1, 2.

Material: $50^{\circ}, 4 \%, 13$ juv. in $A$. cervicornis; 2 juv. in $A$. prolifera.

Size: From $1.1 \times 3.0 \mathrm{~mm}$ juv. to $6.1 \times 4.1$ $\mathrm{mm}$ ㅇ.

Range: Florida keys to Islas Albrolhos, Brazil, Bahamas, Curaçao.

Genus Paraliomera Rathbun, 1930

Paraliomera longimana (A. Milne Edwards, 1865)

Ref.: Rathbun, 1930: 243, pl. 101 figs. 1-3.

Material: $30^{\circ}, 9 \circ$ in A. prolifera; $40^{\circ}, 3 \%$ in A. palmata.

Size: From $5.1 \times 2.3 \mathrm{~mm}$ \& to $10.4 \times 5.5 \mathrm{~mm}$ on.

Range: Florida to northern South America, Bermuda.

Remarks: All specimens were found inside cavities and tunnels in the dead portion of the colonies. The tunnels are generally deep and sometimes cross the bases of the colony. The 
colonies had to be completely broken up to remove specimens.

Genus Phymodius A. Milne Edwards, 1863

Phymodius maculatus (Stimpson, 1860)

Refs.: Rathbun, 1930: 295, pl. 136; Rodríguez, 1980: 355.

Material: $20^{\circ}, 1 \%$ in $A$. cervicornis; 1 juv. in $A$. prolifera.

Size: From $3.0 \times 2.0 \mathrm{~mm}$ juv. to $18.9 \times 16.7$ mm ơ.

Range: Bahamas and Florida Keys, Caribbean sea.

Genus Tetraxanthus Rathbun, 1898

Tetraxanthus bidentatus (A. Milne Edwards, 1880)

Ref.: Rathbun, 1930: 458, pl. 184.

Material: $10^{\circ}$ in A. cervicornis.

Size: $3.8 \times 2.5 \mathrm{~mm}$.

Range: North Garolina and Gulf of Mexico to Cape Frio, Brazil.

Remarks: A new report for Venezuela.

Family PORTUNidAe Rafinesque, 1815

Genus Portunus Weber, 1795

Portunus vocans (A. Milne Edwards, 1878)

Ref.: Rathbun, 1930: 60, pl. 25 figs. 8, 9.

Material: $10^{\circ}$ in $A$. prolifera.

Size: $8.7 \times 5.6 \mathrm{~mm}$.

Range: Cuba, Jamaica, Haiti, and Ascension Island in the South Atlantic; between 35 and $220 \mathrm{~m}$.

Remarks: A new report for Venezuela; this tiny portunid can be found in calcareous sand, coral rubble and in sea grass flats.

Superfamily OXYRHINCHA

Family MajIDAE; Subfamily Mithracinae

Genus Mithrax Latreille, 1817

Mithrax sculptus (Lamarck, 1818)

Ref.: Rathbun, 1925: 442, figs. 125, 126, pl. 152.
Material: $2260^{\circ}, 76 \%, 11 \%$ ov., 130 juv. in $A$. cervicornis; $480^{\circ}, 37$ \&, 6 ov., 15 juv. in $A$. prolifera; $10^{\circ}, 1$ \& , 8 juv. in $A$. palmata.

Size: From $8.2 \times 7.2 \mathrm{~mm}$ juv. to $26.9 \times 24.9$ $\mathrm{mm} \mathrm{o}^{\circ}$.

Range: Caribbean Sea; in grass flats, coral rubble and rocks; shallow water to $60 \mathrm{~m}$.

Remarks: This crab was commonly found on the dead portions of the colonies, and was seen feeding on the associated algae.

Mithrax forceps (A. Milne Edwards, 1875)

Refs.: Rathbun, 1925: 431, pl. 156; Williams, 1965: 258, figs. 238,245 e.

Material: $130^{\circ}, 6$ \&, 16 juv. in $A$. prolifera; $140^{\circ}, 15 \&, 38$ juv. in $A$. cervicornis.

Size: From $1.1 \times 1.1 \mathrm{~mm}$ juv. to $12.3 \times 11.2$ mm $Q$.

Range: From North Carolina to Rio de Janeiro, Brazil; shallow water to $50 \mathrm{~m}$.

Remarks: As with $M$. sculptus, this species was commonly observed feeding on the dead portions of the colonies.

Genus Microphris H. Milne Edwards, 1851

Microphris bicornutus (Latreille, 1825)

Refs.: Rathbun, 1925: 489, fig. 139, pl. 173; Williams, 1965: 259, figs. 239, 245 f; Rodríguez, 1980: 293, pl. 30.

Material: $260^{\circ}, 3$ o ov., 51 juv. in A. cervicornis; $10^{\circ}, 1$ \&, $1 \%$ ov., 2 juv. in $A$. prolifera; 19 in $A$. palmata.

Size: From $1.7 \times 2.4 \mathrm{~mm}$ juv. to $17.8 \times 23.9$ mm ơ.

Range: North Carolina to Santa Catarina, Brazil; to $67 \mathrm{~m}$ in mangrove roots, coral and Thalassia.

Remarks: Observed only on the dead portions of the colonies.

\section{DISCUSSION}

The 30 species found in 3 acroporid coral species in the Archipiélago de Los Roques is a surprisingly large number if compared to the 25 
and 15 decapod species reported by Patton (1966) and Garth (1974) for acroporids in Sri Lanka and the Maldive Islands respectively, located both in the Indo-Pacific where the pool of decapod species is considerably larger than in the Caribbean. However, their sampling methods appear not to be adequate enough to prevent the escape of the associated fauna. Thus, the lack of information on crustaceans found on acroporid corals in the Caribbean and for that matter in any other region of the world, plus the fact that different methods have been used in studying this fauna, renders difficult the comparative analysis of our findings.

Researches on the decapod community of coral species are few. In the Pacific, Abele (1976) found 55 species in the coral Pocillopora damicornis (Linnaeus, 1758), Edwards \& Emberton (1980) sampled 47 species in Stylophora pistillata Esper, 1797, and Coles (1980) located 127 species in Pocillopora meandrina Dana, 1846, and indicated that both live and dead coral were sampled. In the subtropical Atlantic, Reed et al. (1982) reported 52 decapod species for the coral Oculina varicosa Lesueur, 1821, whereas McCloskey (1970) found 19 species on an apparently similar species, Oculina arbuscula (Dana, 1848).

At first hand it seems that the above coral species have a richer decapod community than the 3 species of Acropora in Los Roques. This difference could be due to the fact that the other coral species are structurally more complex than Acropora. However, at present it is impossible to make any solid comparison of decapod communities among coral species, or geographical areas.

Most of the decapod species found in the present study were located in the dead portions of the colonies. Possibly they utilize these areas as refuges against predators or as reproductive and feeding shelters. Only Domecia acanthophora seems to be a true commensal that depends on the live coral tissue, as reported by Patton (1967). It appears also that the structural deformations produced by this crab in branches of $A$. palmata are utilized as reproductive shelters by the large ovigerous females, and this could ac- count for the fact that the ovigerous/nonovigerous ratio of females collected in $A$. palmata was $2: 1$, while it was $1: 1$ in $A$. prolifera and $A$. cervicornis. This result was confirmed by our observations that most crevices in $A$. palmata were occupied by ovigerous females of $D$. acanthophora. Further research could prove that these crevices not only serve as resting places, as indicated by Patton (1967), but as shelters for reproduction and brood care as well.

The geographical distribution of the decapod species found in the three species of Acropora from the Archipiélago de Los Roques is primarily insular with a strong affinity in species composition with the South Florida (19 species shared), the Caribbean and Bermuda (18 species shared), and the West Indian Provinces (16 species shared). The weakest affinities seem to exist with the Tropical Brazilian (12 species shared) and the Caribbean Provinces (10 species shared). Three of the species also occur in the Eastern Atlantic and two in the South Atlantic. Although these affinities may indicate possible biogeographic relationships and patterns in population mixing and/or existence of biogeographic barriers, the relationships should be taken with caution as they might simply reflect differential sampling efforts conducted in the different provinces.

The caridean Latreutes fucorum, the palaemonid Alpheus simus, the anomuran Pagurus brevidactylus and the brachyurans Portunus vocans and Tetraxanthus bidentatus constitute new reports for Venezuela.

\section{ACKNOWLEDGEMENTS}

We thank the staff of the Fundación Científica Los Roques at Dos Mosquises, and at Caracas, for their help and enthusiasm throughout the project, particularly Ernesto Weil for his assistance in the logistics, Dr. Gilberto Rodríguez for confirming some of the identifications, and Pablo Rodríguez for drawing the map. This project was made possible by a grant of CONICIT.

\section{REFERENCES}

Abele, L. G., 1976. Comparative species richness in fluctuating and constant environments: coralassociated decapod crustaceans. Science, 192: 461463. 
Abele, L. G. \& W. Patton, 1967. The size of corals and the community biology of associated decapod crustaceans. J. Biogeogr., 3: 35-47.

Austin, A. D., S. A. Austin \& P. F. Sale, 1980. Community structure of the fauna associated with the coral Pocillopora damicornis (L.) on the Great Barrier Reef. Aust. J. mar. freshwat. Res., 31: 163-174.

BAK, R. P. M. \& D. R. Robertson, 1980. Pair formation in coral inhabiting hermit crabs. Oecologia, 47: 267269.

Castro, P., 1976. Brachyuran crabs symbiotic with scleractinian corals: a review of their biology. Micronesica, 12: 99-110.

Chace, F. A., 1972. The shrimps of the SmithsonianBredin Caribbean Expeditions with a summary of the West Indian shallow-water species (Crustacea: Decapoda: Natantia). Smithson. Contr. Zool., 98: i-x, 1-179.

Coles, S. L., 1980. Species diversity of decapods associated with living and dead reef coral Pocillopora meandrina. Mar. Ecol. Prog. Ser., 2: 281-291.

Coutière, H., 1909. The American species of snapping shrimps of the genus Synalpheus. Proc. U.S. natn. Mus., 36 (1659): 1-93.

Criales, M. M. \& L. Corredor, 1977. Aspectos etológicos y ecológicos de camarones limpiadores de peces (Natantia: Palaemonidae, Hippolytidae, Stenopodidae). An. Inst. Inv. mar. Punta Betín, 9: 141156.

Crosnier, A. \& J. Forest, 1966. Crustacés Décapodes: Alpheidae, 19. In: Campagne de la Calypso dans le Golfe de Guinée et aux îles Principe, Sao Tomé et Annobon (1956), et Campagne aux Iles du Cap Vert (1959), VII. Annls. Inst. oceanogr. Monaco, 44: 199-315.

Edwards, A. \& H. Emberton, 1980. Crustacea associated with the scleractinian coral Stylophora pistillata (Esper) in the Sudanese Red Sea. J. exp. mar. Biol. Ecol., 48: 225-240.

Forest, J., 1954. Sur un Pagure littoral nouveau de la Martinique, Paguristes cadenati sp. nov. Bull. Mus. natn. Hist. nat. Paris, (2) 26: 353-357.

Garth, J. S., 1974. Decapod crustaceans inhabiting reef-building coral of Ceylon and the Maldive Islands. J. mar. biol. Ass. India, 15: 195-212.

- , 1978. Marine biological investigations in the Bahamas, 19. Decapoda Brachyura. Sarsia, 63 (4): 317-333.

Glynn, P. W., 1980. Defense by symbiotic Crustacea of host corals elicited by chemical cues from predators. Oecologia, 47: 287-290.

Gore, R. H. \& L. G. Abele, 1976. Shallow water porcelain crabs from the Pacific Coast of Panama and adjacent Caribbean waters (Crustacea: Anomura: Porcellanidae). Smithson. Contr. Zool., 237: i-iv, 1-30.

Guérin-Méneville, F. E., 1856. Crustáceos. In: R.
DE la SAgra ed., Historia física, política y natural de la Isla de Cuba. Historia natural (Atlas), 7: 1-88 (A. Bertrand, Paris).

Guinot, D., 1964. Les trois espèces du genre Domecia (Decapoda, Brachyura): D. hispida Eydoux \& Souleyet, D. glabra Alcock et D. acanthophora (Desbonne \& Schramm). Crustaceana, 7: 267-283.

Holthuis, L. B., 1951. A general revision of the Palaemonidae (Crustacea Decapoda Natantia) of the Americas, 1. The subfamilies Euryrhynchinae and Pontoniinae. Occ. Pap. Allan Hancock Found., 11: 1-332, pls. 1-63.

Knudsen, J. W., 1967. Trapezia and Tetralia (Decapoda: Brachyura: Xanthidae) as obligate ectoparasites of pocilloporid and acroporid corals. Pacif. Sci., 21: 51-57.

McCloskey, L. R., 1970. The dynamics of the community associated with a marine scleractinian coral. Int. Revue ges. Hydrobiol., 55: 13-81.

Patton, W. K., 1966. Decapod Crustacea commensal with Queensland branching corals. Crustaceana, 10: 271-295.

- , 1967. Studies on Domecia acanthophora, a commensal crab from Puerto Rico, with particular reference to modifications of the coral host and feeding habits. Biol. Bull., 132: 56-67.

Prahl, H. V., F. Gull \& M. Grogl, 1978. Crustáceos decápodos comensales del coral Pocillopora damicornis L. en la Isla de Gorgonia, Colombia. An. Inst. Inv. mar. Punta Betín, 10: 81-93.

Provenzano, A. J., 1959. The shallow water hermit crabs of Florida. Bull. mar. Sci. Gulf Caribb., 9: 349-420.

- , 1961. Note on Paguristes cadenati, a hermit crab new to Florida. Quart. J. Fla. Acad. Sci., 23: 325-327.

Rankin, W. M., 1898. The Northrop collection of Crustacea from the Bahamas. Ann. N.Y. Acad. Sci., 11: 225-258.

Rathbun, M. J., 1925. The spider crabs of America. Bull. U.S. natn. Mus., 129: i-xx, 1-613, pls. 1-283.

- , 1930. The cancroid crabs of America of the families Euryalidae, Portunidae, Atelecyclidae, Cancridae and Xanthidae. Bull. U.S. natn. Mus., 152: i-vi, 1-609, pls. 1-230.

Reed, J. K., R. H. Gore, L. E. Scotto \& K. A. Wilson, 1982. Community composition, structure, areal and trophic relationships of decapods associated with shallow- and deep-water Oculina varicosa coral reefs: Studies on decapod Crustacea from the Indian River region of Florida, 24. Bull. mar. Sci., 32 (3): 761-786.

Rodríguez, G., 1980. Los Crustáceos Decápodos de Venezuela: 1-444 (Inst. Venez. Inv. cient. Publicaciones, Caracas).

Schmitr, W. L., 1924. Bijdragen tot de kennis der fauna van Curaçao. Resultaten eener reis van Dr. C. 
$\mathrm{J}$. van der Horst in 1920. The macruran, anomuran and stomatopod Crustacea. Bijdr. Dierk., 23: 61-82, pl. VIII.

VÉlez, M. M., 1977. Distribución y ecología de los Majidae (Crustacea: Brachyura) en la región de
Santa Marta, Colombia. An. Inst. Inv. mar. Punta Betín, 9: 109-140.

Williams, A. B., 1965. Marine decapod crustaceans of the Carolinas. Fishery Bull. Fish Wildl. Serv. U.S., 65: 1-298.

First draft received 24 February 1983

Revised draft received 15 May 1984 